\title{
KONSTRUKSI NILAI BARANG VIRTUAL DALAM FENOMENA REAL MONEY TRADE
}

\author{
Oleh: \\ Muhammad Arief Rahadian
}

\begin{abstract}
Abstrak
Artikel ini membahas tentang fenomena Real Money Trade (RMT), atau pembelian barang virtual dengan mata uang nyata dalam game online. Studi sebelumnya menempatkan RMT dalam kerangka ekonomi makro; Industri video game menciptakan struktur yang mengharuskan pemain menghabiskan waktu puluhan jam untuk mendapatkan sebuah barang langka.Hal ini berimplikasi pada munculnya pemain yang mengorbankan waktunya untuk mencari barang langka, dan menjualnya.Pandangan tersebut mengandung kelemahan karena pemain memiliki penilaian subjektif terhadap barang virtual.Hal ini memungkinkan pemain untuk menilai barang yang dikondisikan oleh pasar sebagai barang langka menjadi barang yang tidak bernilai. Penilaian subjektif inilah yang memungkinkan pemain untuk menjual barang apapun, selama ada pemain lain yang menganggap barang tersebut bernilai. Argumen utama tulisan ini adalah pemain memiliki ruang gerak dalam memaknai nilai barang virtual.Metode kualitatif digunakan untuk mengumpulkan data dari enam informan. Studi ini menemukan bahwa pemain memiliki kapasitas untuk memaknai barang secara subjektif, meskipun secara konstan dipengaruhi oleh berbagai faktor sosial seperti teman bermain, keluarga, dan pasar. Studi ini juga mengungkapkan bahwa nilai barang virtual bersifat dinamis bagi pemain, sehingga pemain yang awalnya berposisi sebagai pembeli dapat berubah menjadi penjual ketika barang yang dibelinya tidak lagi dinilai berharga.
\end{abstract}

\begin{abstract}
This paper speaks about the phenomena of Real Money Trade (RMT). RMT is defined as buying virtual objects using real currency in the world of online games. Previous studies tend to put RMT in the field of macroeconomics; video game companies create a structure, which a player is forced to spend a lot of time in order to get one particular rare object. Thus, players with a sole purpose of collecting rare items in order to get real currency by selling it were born. But that view has some flaws. Player, as an individual can attach their own subjective meaning towards the virtual object they desired, neglecting the rarity status created by the market. Subjective meaning also enables players to sell any objects, as long as there are players desiring that object. The main argument of this paper is a player has the capacity to attach their own subjective meaning to the virtual objects. Qualitative method was used to gather the data from six informants. This paper finds that players have the capacity to subjectively attach their own meaning towards virtual object, despite the constant influence from social factors such as family, friends, and market. Also, this paper shows that the subjective meaning itself is not fixed. Thus, a buyer can turn into a seller once they think that the virtual object has no value anymore.
\end{abstract}

Keywords: Real Money Trade, Online Games, Value, Subjective Meaning, Sociology 


\section{A. Pendahuluan}

Perkembangan teknologi menghasilkan berbagai fenomena yang terkadang luput dari perhatian para akademisi, sebagai contoh, fenomena Real Money Trade (RMT) (Heeks 2008). RMT sendiri sebenarnya bukan merupakan fenomena yang sama sekali baru. Munculnya RMT dapat dilacak hingga tahun 1987. Transaksi RMT pertama yang tercatat terjadi pada tahun tersebut di dalam gameMulti User Dungeon (MUD) berbasis teks (Hunter 2006).Di Indonesia sendiri, sejarah RMT dimulai dengan hadirnya Ragnarok Online, sebuah Massive Multiplayer Online Role Playing Game (MMORPG) yang dibawa oleh PT. Lyto Datarindo Fortuna pada tahun 2001.Berbagai jenis barang virtual diperjualbelikan mulai dari baju zirah, senjata, aksesoris, hingga karakter game. Jumlah uang yang ditransaksikan juga tidak sedikit, mulai dari ratusan ribu hingga jutaan rupiah. (Intisari: 10, 2004). Munculnya game onlinelain seperti Seal Online dan Rising Force Online, serta publisher game online lain seperti Megaxus dan Playon juga turut mendorong berkembangnya industri game online, serta RMT di Indonesia. Pemain umumnya menggunakan fasilitas chat di dalam game serta media sosial seperti Kaskus dan Facebook untuk mencari penjual atau pembeli.

Pertanyaan yang kemudian muncul adalah mengapa RMT terjadi?. Mengapa pembeli rela mengeluarkan uang untuk barang yang tidak nyata? Sebagai bahan perbandingan, barang virtual dalam sebuah game online dapat terjual di kisaran harga ratusan ribu hingga jutaan rupiah. Ghostring Card dalam Ragnarok Online misalnya, terjual di kisaran harga enam juta rupiah karena kemampuannya untuk membuat pemegangnya tidak dapat diserang.Harga diatas mungkin wajar bagi sebagian orang, karena barang tersebut membuat pemain yang memilikinya tidak dapat dikalahkan. Namun, dalam game online lain seperti DotA II dan sekuel Ragnarok Online, Ragnarok Online II, barang-barang yang banyak diminati justru merupakan barang kosmetik yang tidak memiliki fungsi selain merubah tampilan karakter pemain. Kisaran harga barang virtual kosmetik tersebut juga tidak kalah besar. Sebuah kostum dalam Ragnarok Online II dapat dijual seharga dua juta rupiah, sedangkan satu set kostum dalam DotA II dapat dijual seharga lima puluh ribu sampai jutaan rupiah.

Studi-studi terdahulu umumnya membahas RMT dalam kerangka ekonomi makro; sebagai contoh, Studi dari Heeks yang berjudul Gold Farming: Real-World Production in Developing Countries for the Virtual Economies of Online Games.Dalam studinya, secara sosiologis Heeks menjelaskan bagaimana RMT berkembang menjadi sebuah industri yang berpusat di negara-negara berkembang seperti Republik Rakyat Tiongkok dan Meksiko.Heeks memberikan analisa dalam kerangka makro tentang bagaimana Industri RMT di negaranegara berkembang menopang demand mata uang dan barang-barang in-game di negara-negara maju.Dalam studinya, dapat dilihat bahwa pasar dan kesenjangan ekonomi menjadi faktor utama terjadinya RMT.Pasar, melalui developer dan publisher game merilis, mendesain, serta mengatur distribusi barang virtual yang beredar dalam game online.Pasar kemudian berkolaborasi dengan kesenjangan dan menciptakan rantai permintaan dan penawaran antara pemain dari negara maju dan negara berkembang.

Studi diatas memiliki beberapa kekurangan.Pertama, pasar tidak memiliki kuasa penuh terhadap 
preferensi barang virtual yang dianggap berharga oleh pemain.Pemain tidak selalu mencari barang yang dikondisikan oleh pasar sebagai barang langka. Hal ini dapat dilihat dari banyaknya ragam barang yang dijual dalam proses RMT, terlepas barang tersebut langka, atau tidak. Kedua, terdapat perbedaan pola RMT dari kasus yang dipaparkan oleh Heeks dan kasus yang dibahas dalam penelitian ini.RMT dalam penelitian ini tidak terorganisir dan tidak hanya dilakukan oleh pemain dari kelas ekonomi bawah. Pemain, baik yang berasal dari kelas ekonomi atas, menengah, maupun bawah memiliki motif tersendiri dalam membeli dan menjual barang virtual, dan motif tersebut tidak selalu bersifat ekonomi seperti yang dipaparkan oleh Heeks. Paparan diatas menunjukkan bahwa subjektivitas pemain menjadi kunci utama terjadinya RMT, disamping pasar dan kesenjangan.Pemain memiliki kapasitas untuk memaknai barang virtual, meskipun secara konstan mendapat paparan dari faktor-faktor eksternal.

\section{B. Metode Penelitian}

Penelitian tentang konstruksi nilai barang virtual dalam fenomena RMT ini menggunakan metode kualitatif.Informan penelitian dipilih secara snowball dengan kriteria sebagai pemain game, dan terlibat dalam RMT dalam kurun waktu satu tahun terakhir. Terdapat enam pemain game yang menjadi informan dalam penelitian ini. Informan pertama, Dex, adalah pemain game yang berasal dari kelas atas dan berposisi relatif sebagai pembeli. Informan kedua, Jadeith, adalah pemain game yang berasal dari kelas menengah dan berposisi relatif sebagai pengamat. Informan ketiga, Stitch, adalah pemain game dari kelas menengah dan berposisi sebagai penjual sekaligus pembeli. Informan keempat, Skre, adalah pemain game dari kelas menengah dan berposisi relatif sebagai pembeli, namun kemudian berubah menjadi penjual. Informan kelima, Caligula, merupakan pemain game dari kelas atas dan berposisi relatif sebagai pembeli. Sedangkan informan terakhir, Cadreva, adalah pemain game dari kelas atas dan berposisi sebagai penjual.

Pengumpulan data dilakukan dengan cara wawancara mendalam dan online interview.Wawancara dengan Dex, Jadeith, Stitch, Skre dan Caligula dilakukan secara langsung.Wawancara dengan informan terakhir, Cadreva, dilakukan secara online di dalam game DotA II bersamaan dengan transaksi pembelian barang virtual yang dilakukan oleh peneliti. Selain wawancara, data juga didapatkan dari hasil observasi partisipatoris yang dilakukan peneliti selama proses penelitian berlangsung. Proses pengumpulan data memakan waktu sekitar tiga bulan, dari bulan Februari 2015 hingga Mei 2015.

\section{Nilai Barang Virtual dalam Kerangka Berpikir Georg Simmel}

Manusia memberikan nilai ke berbagai hal: hubungan, binatang, makanan, kendaraan dan sebagainya. Dalam kerangka berpikir Simmel, nilai terbentuk saat manusia menciptakan benda, memisahkan dirinya dari benda dan berusaha untuk melampaui jarak serta rintangan yang membatasinya dengan benda tersebut (Simmel dalam Ritzer, 2008).Pandangan Simmel bahwa manusia berusaha untuk melampau jarak yang diciptakannya sendiri menegaskan bahwa nilai adalah sesuatu yang bersifat subjektif (Sotiropoulou 2010).Hal tersebut secara eksplisit dinyatakaan oleh Simmel (1900) di dalam bukunya melalui pernyataan 
"nilai sebuah barang tidak melekat pada objeknya, melainkan subjeknya".

Simmel kemudian menjelaskan bahwa posisi objek berpengaruh terhadap penilaian subjek terhadapnya. Objek yang terlalu dekat dan mudah didapatkan tidak akan memiliki nilai bagi manusia, begitu pula objek yang terlalu jauh dan sulit untuk didapatkan. Sebuah objek harus berada dalam posisi yang tidak terlalu jauh dan tidak terlalu dekat agar memiliki nilai di mata subjeknya. Lebih lanjut, Simmel (1900) mengatakan bahwa terdapat beberapa faktor yang mempengaruhi proses penilaian subjek terhadap objek yaitu waktu yang diperlukan untuk mendapatkannya, kelangkaannya, kesulitan dalam mendapatkannya serta pengorbanan yang harus dibuat untuk memperoleh objek tersebut (Ritzer, 2008). Proses penilaian inilah yang mendasari terjadinya sebuah pertukaran. Pertukaran merupakan cara manusia untuk melampaui jarak antara dirinya dan objek yang diinginkannya. Simmel mengemukakan dua asumsi utama dalam pertukaran: Pertama, hubungan sosial diperlukan sebagai prasyarat terjadinya pertukaran, dan kedua, pertukaran selalu terjadi dalam kondisi yang setara dalam definisi masing-masing pihak (Simmel, 1900).

Barang virtual, layaknya objek pada umumnya memiliki nilai subjektif yang dilekatkan oleh individu terhadapnya.Nilai sebuah barang virtual menjadi penting, khususnya bagi pemain game online.Konteks "jarak" yang tidak terlalu jauh dan tidak terlalu dekat agar sebuah objek dihargai dapat dikaitkan dengan status subjek sebagai pemain game online.Barang virtual hanya bernilai bagi orang yang bermain dan memaknai barang tersebut sebagai sesuatu yang bernilai.Jarak pemain terhadap barang virtual yang diinginkannya menjadi sesuatu hal yang menarik untuk dianalisa lebih lanjut.
Mengapa seseorang dapat berada di posisi yang tepat untuk memaknai barag virtual sebagai sesuatu yang bernilai? Mengapa barang virtual dapat tidak memiliki nilai bagi orang lain?. Hal inilah yang akan dikaji lebih lanjut dalam penelitian ini.

\section{Mengenal Berbagai Komoditas Virtual dalam Real Money Trade}

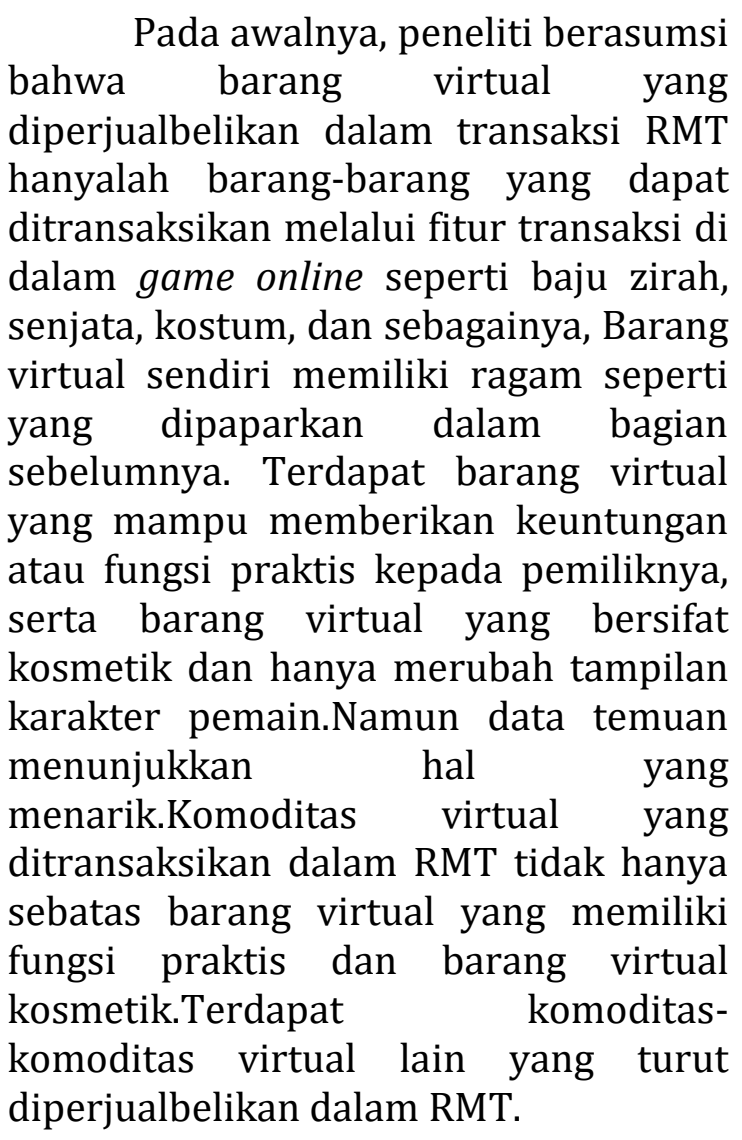

"RO 1 mah paling gue beli zeny (mata uang dalam Ragnarok Online I \& II) doang, beli, waktu masih cupu banget ya gue cuma beli dua juta zeny tuh, satu jutanya 10 ribuan, guee beli sama mas-mas warnet. Aduh polospolos banget tuh janjian sama temen beli gituan."

(Hasil wawancara dengan Cadreva tanggal 26 Maret 2015) 
Kutipan wawancara di atas menunjukkan bahwa dalam RMT, uang virtual merupakan bagian dari komoditas virtual, atau barang yang turut diperjualbelikan dalam dunia game online. Selain Caligula, Stitch dan Skre juga membeli mata uang virtual dalam transaksi RMT pertama mereka. Sebaliknya, informan lain yang berposisi sebagai penjual, Cadreva, menjual mata uang virtual dalam transaksi RMT pertamanya.

"Pertama kali gua dapet duit cash itu, mata uang game nya sih yang gua pertama kali. Gua kumpul-kumpulin barang-barang hasil farming gua jadiin zeny, terus akhirnya gua jual lah semua, zeny nya itu, ibaratnya zeny lah kalo di RO ya, itu orang langsung gitu ... Dulu inget banget gua, tiga juta kalo gasalah dia bawa uang."

(Hasil wawancara dengan Caligula tanggal 10 Maret 2015)

Bagi Simmel, uang merupakan simbol tanpa nilai intrinsik, sesuatu yang kosong dan tidak bermakna. Hal ini juga berlaku dalam dunia virtual.Informan menggunakan uang virtualnya untuk membeli konsumsi dan equipment, atau dengan kata lain, melampaui jarak antara dirinya dengan barang virtual yang menjadi hasratnya.Namun temuan bahwa uang virtual ternyata merupakan bagian dari komoditas yang diperjualbelikan dalam RMT menjadi hal yang tidak dapat dijelaskan melalui kacamata Simmel.

Selain mata uang virtual, terdapat barang lain yang turut diperjualbelikan dalam RMT. Jenis komoditas virtual kedua adalah barang yang memiliki pengaruh langsung terhadap kekuatan karakter, seperti baju zirah (armor), senjata (weapon). Baju zirah yang terbuat dari batu berharga akan memberikan kekuatan perlindungan yang lebih tinggi daripada baju zirah yang terbuat dari kulit. Dalam penelitian ini, barang yang memiliki pengaruh langsung terhadap kekuatan karakter akan disebut sebagai "barang yang memiliki nilai guna". Barangbarang yang memiliki nilai guna ini biasanya didapatkan sebagai hadiah dari mengalahkan boss monster, monster terkuat dalam satu area, atau dengan membuatnya sendiri. Proses pembuatan senjata dalam game online merupakan hal yang rumit, karena pembuatan senjata hanya bisa dilakukan oleh pekerjaan tertentu dan memiliki kemungkinan gagal yang besar. Besarnya pengorbanan untuk mendapatkan barang, serta langkanya barang menjadi alasan utama mengapa barang-barang ini memiliki nilai jual dan harga yang spektakuler.

"Barang rare itu bisa dari dropan boss, dan dropan yang jarang, pokoknya yang tipe-tipe rare banget, jadi tuh susah drop nya, ada juga dari plus nya, yang upgrade nya dari upgrade gitu masuk crafting segala macem. Temen gue nih ya di archeage dia tuh pernah dapet, dia crafting pokoknya yang paling bagus lah, dapet tiga set dia ngejual 80 juta di dolarin berapa?." (Hasil wawancara dengan Jadeith pada tanggal 18 Februari 2015)

Selain mata uang dan barang yang memiliki nilai guna, terdapat komoditas lain yang turut diperjualbelikan dalam RMT, yaitu barang kosmetik. Barang kosmetik adalah barang yang tidak memiliki nilai guna, atau dengan kata lain, tidak mempengaruhi kekuatan karakter.Namun, barang kosmetik dapat secara subjektif membuat tampilan karakter lebih menarik. Dalam Ragnarok Online II, barang kosmetik disebut sebagai kostum, sedangkan 
dalam DotA II, seluruh barang virtual bersifat kosmetik dan tidak mempengaruhi jalannya permainan. Meskipun barang kosmetik tidak memiliki pengaruh terhadap kekuatan karakter, barang kosmetik relatif merupakan barang yang paling banyak dicari oleh pemain menurut keterangan informan. "Ya...pertama sih pasti kosmetik kalo emang RPG itu kaya kostum-kostum itu pasti, zeny juga pasti, terus barang-barang event yang susah didapetinnya, musti pay to win tuh pasti mahal" , ujar Stitch.

Bahasan di atas menunjukkan bahwa mata uang virtual, barang dengan nilai guna, serta barang kosmetik merupakan tiga jenis komoditas yang diperjualbelikan dalam transaksi RMT. Data temuan sebenarnya menunjukkan komoditas lain yang turut diperjualbelikan dalam transaksi RMT, yaitu karakter pemain. Memperkuat karakter dalam game online membutuhkan waktu dan sumberdaya yang cukup besar. Oleh karena itu, karakter juga merupakan komoditas yang turut diperjualbelikan dalam transaksi RMT. Dex menjual karakter beserta resep senjata yang dimiliki oleh karakter tersebut, sama dengan Stitch yang menjual karakter dan equipmentnya sekaligus. Berbeda dengan Dex dan Stitch, Skre mencoba menjual karakternya, namun tidak mendapatkan pembeli. Pertanyaan selanjutnya adalah, mengapa keempat barang yang sama sekali berbeda tersebut memiliki nilai dalam transaksi RMT? Bagaimana cara barang virtual dimaknai bernilai atau tidak bernilai?

\section{Faktor Sosial dalam Proses Penilaian Barang Virtual}

$\begin{array}{crr}\text { Pertukaran } & \text { merupakan } \\ \text { fenomena hilangnya jarak antara }\end{array}$

pembeli dan barang yang diinginkannya. Jika dalam masyarakat tradisional pertukaran terjadi dengan menggunakan metode barter, maka dalam masyarakat modern pertukaran dilakukan dengan menggunakan perantara: uang. Terlepas dari kondisi barang yang bersifat virtual, RMT tetap berjalan dengan menggunakan uang nyata sebagai media pertukaran. Namun mengapa individu menginginkan sesuatu yang bersifat virtual, dan bahkan rela membayar untuk barang virtual tersebut?Jawaban dari pertanyaan ini terletak dalam konsepsi Simmel mengenai nilai.

$\begin{array}{ccc}\begin{array}{c}\text { Setiap } \\ \text { penilaian }\end{array} & \begin{array}{c}\text { individu } \\ \text { subjektif }\end{array} & \text { memiliki } \\ \text { terhadap }\end{array}$
barang.Penilaian ini muncul saat individu merasakan jarak antara diri dan barang, lalu mencoba melampauinya. Bagi Simmel, sebuah barang akan bernilai apabila jarak antara individu dan barang tersebut tidak terlalu jauh, atau tidak terlalu dekat. Jika jarak individu terlalu dekat, maka barang tersebut tidak akan dianggap bernilai, namun jika jarak barang terlalu jauh, maka individu tidak akan tertarik untuk memiliki barang tersebut.

Jika dielaborasi lebih lanjut, dapat disimpulkan bahwa saat membahas mengenai posisi individu dan jaraknya terhadap barang, Simmel sebenarnya sedang berbicara tentang latar belakang individu.Nilai sebuah barang berbanding relatif dengan latar belakang individu, seperti intensitas sosialisasi terkait barang tersebut, serta kelas sosialnya.Pandangan Simmel mengenai posisi ini relevan jika digunakan untuk menganalisa data temuan penelitian ini.Keenam informan memiliki posisi atau latar belakang yang mirip. Keenamnya mulai bermain game sejak masih berada di bangku SD dan SMP. 
Dex, Jadeith, Stitch dan Caligula mulai bermain game online sejak duduk di bangku SD, sedangkan Caligula dan Cadreva mulai bermain saat duduk di bangku SMP.Lantas apakah kesamaan latar belakang membuat kesamaan nilai barang di mata setiap informan?Tentu saja tidak.Kesamaan latar belakang hanya bisa membuktikan bahwa keenam informan berada di jarak yang sesuai untuk memberikan nilai kepada barang virtual. Fakta bahwa terdapat informan yang menjadi penjual menunjukkan bahwa barang virtual ternyata dapat menjadi tidak bernilai sama sekali. Hal inilah yang menarik untuk dikaji lebih lanjut, siapakah penjual dan pembeli dalam RMT, serta bagaimana nilai barang dikonstruksikan oleh penjual dan pembeli?.

\section{Nilai Barang Virtual di Mata Pelaku Real Money Trade}

Hasrat untuk membeli sebuah barang hadir saat individu menilai barang tersebut secara subjektif. Proses penilaian subjektif tersebut hanya bisa terjadi apabila individu berada di posisi yang tepat, tidak terlalu jauh atau tidak terlalu dekat dengan barang. Jarak "yang tepat" inilah yang kemudian dicoba dilampaui oleh pembeli dengan menggunakan uang sebagai perantaranya.

Dalam penelitian ini, masingmasing informan memiliki jarak dan penilaian subjektif yang berbeda terhadap barang virtual.Dex misalnya, seorang mahasiswa yang tinggal dan hidup mandiri di daerah Kebon Jeruk.Berbagai faktor membuat Dex berada di jarak yang tepat untuk menilai barang virtual sebagai sesuatu yang bernilai. Dex mulai bermain game online sejak duduk di bangku SD, berawal dari ajakan saudaranya. Dex yang merasa tertarik kemudian mengajak temantemannya untuk ikut
bermain.Keberadaan teman yang turut bermain bersamanya inilah yang kemudian membuat Dex terus bermain dan mencoba game-game baru.

"Gue mulai kenal warnet itu garagara CS. Counter strike. Pertama kali gue maen itu diajak saudara gue.Ke warnet yang ada di SCBD. Sekarang udah ga ada. . . Akhirnya gue pas $S D$ mikir gitu kayaknya ada warnet deket sekolah gue, akhirnya gue ngajak temen-temen gue coba yuk main CS main CS, coba rame-rame main CS. Abis dari situ akhirnya malah main banyak game."

(Hasil wawancara dengan Dex tanggal 10 Februari 2015)

Bagi Dex, dalam Ragnarok Online II, barang virtual yang paling bernilai adalah barang dengan nilai guna. Dex menilai sebuah barang virtual dari kemampuan barang tersebut untuk membuat karakternya semakin kuat. Dex merasa apabila karakternya menjadi semakin kuat, maka ia pun akan semakin terkenal. Tujuan utama Dex saat melakukan pembelian adalah kejayaan, Dex ingin dirinya dikenal dan "megang" dalam dunia Ragnarok Online II. Dengan kata lain, bagi Dex, barang virtual, khususnya yang memiliki nilai guna mempunyai status sosial yang melekat di dalamnya.

Berbeda dengan nilai barang virtual di Ragnarok Online II, dalam DotA II Dex menilai barang virtual sebagai sesuatu yang tidak bernillai. Bagi Dex, barang virtual di DotA II hanya berguna untuk dijual kembali, karena barang virtual tersebut tidak memiliki fungsi dan hanya bersifat kosmetik. Alasan Dex meembeli barang virtual di DotA II adalah untuk menjualnya kembali dengan harga yang lebih mahal."Temen lagi BU (butuh uang), jadi daripada gue pinjemin mending gue beli murah bundle dia 
hahahaha... Hahaha kan nampung Set, terus gue jual harga normal deh.", ucap Dex.

Informan ketiga, Stitch, juga berada dalam posisi yang tepat untuk menilai barang virtual sebagai sesuatu yang bernilai. Stitch sendiri mulai bermain game online sejak duduk di bangku SD. Selain bermain, Stitch juga membayar jasa bot untuk menaikkan level karakternya, dan bahkan belajar untuk menggunakan program bot sendiri.Penilaian Stitch terhadap barang virtual berubah seiring waktu.Awalnya Stitch menilai barang virtual dengan nilai guna sebagai barang yang paling bernilai. Kepuasan Stitch dalam bermain game online dulunya datang dari membunuh pemain lain dalam arena pertarungan, dan untuk membunuh pemain lain, Stitch membutuhkan equipment yang terbaik. Transaksi RMT yang Stitch lakukan pada masa-masa awal bermain game online selalu melibatkan barang dengan nilai guna, bukan barang kosmetik.

Namun dalam Ragnarok Online II dan DotA II, Stitch justru menilai barang kosmetik sebagai sesuatu yang lebih bernilai daripada barang dengan nilai guna. Stitch bahkan rela menghabiskan uangnya untuk berjudi demi mendapatkan kostum yang Ia inginkan. Dalam beberapa waktu, Stitch merasa bahwa barang kosmetik merupakan sesuatu yang sangat bernilai sampai Ia tidak ingin melepas atau menjualnya."Engga gue simpen dulu, gara-gara dulu tim raid gue kan dulu tuxedo semua kan, posan doang tuh di diskriminasi ga pake tuxedo.",ujar Stitch.

Pada waktu yang lain, Stitch justru melepas barang-barang virtual yang dimilikinya, bahkan menjual karakternya. "Demi tiga juta, eh 2,7, 2,7 apa 2,8 gua lupa, gue ke Bandung, 2,8 juta men gue bolos kuliah anjir, terbang ke bandung deeer.", ungkapnya. Terdapat beberapa poin yang menarik untuk dianalisa berdasarkan paparan di atas.Poin pertama adalah bagaimana pemaknaan subjektif informan yang berbeda-beda. Dex menganggap bahwa barang dengan nilai guna merupakan barang yang paling bernilai, sedangkan Stitch menganggap barang kosmetiklah yang paling banyak dicari dan diinginkan oleh pemain game. Poin kedua adalah bagaimana pemaknaan akan nila suatu barang dapat berubah dari waktu ke waktu.

Pada masa awal bermain game online, Stitch memilih untuk membeli barang dengan nilai guna. Namun sekarang, Stitch lebih memilih untuk membeli barang-barang kosmetik.Hal ini menunjukkan bahwa nilai sebuah barang bersifat dinamis, atau dengan kata lain, jarak antara individu dan barang selalu berubah seiring dengan berjalannya waktu.

Lalu apakah implikasi dari berubahnya penilaian subjektif individu terhadap barang?Implikasi dari hal tersebut adalah berubahnya posisi pembeli, menjadi penjual.Berbeda dengan pembeli, penjual justru memberi jarak antara diri dengan barang yang dimilikinya. Hadirnya jarak antara diri dengan barang ditandai dengan uang yang didapatkan oleh penjual dari proses transaksi. Lalu apakah uang merupakan tujuan akhir dari penjual?Tentu saja tidak.

Seperti yang sudah dijelaskan dalam bagian sebelumnya, uang merupakan sesuatu yang tidak memiliki makna. Apa yang diinginkan oleh penjual bukanlah uang, melainkan pemenuhan akan hasratnya terhadap barang lain. Dengan mengorbankan jarak antara dirinya dengan barang yang Ia jual, penjual dapat melampaui jarak antara dirinya dengan barang lain yang diinginkannya. Praktek seperti ini menempatkan transaksi layaknya permainan give and take, dimana individu memberi sesuatu untuk orang 
lain, dan mendapatkan barang lain sebagai gantinya. Konsepsi pertukaran ini relevan dan berlaku dalam RMT."Buat jajan-jajan, beli baju ... Belibeli, beli baju, Ih kok miniset! Beli bajubaju lucu, cewek-cewek, ya gitu beli perlengkapan-perlengkapan pribadi sama nongkrong-nongkrong lucu.", ujar Skre

Skre bukan satu-satunya yang menjual, atau dalam bahasa Simmel, mengorbankan jarak antara dirinya dengan barang virtual yang dimilikinya untuk mendekatkan diri dengan barang lain. Dalam kasus ini, informan lain yaitu Dex, Stitch dan Cadreva juga menjual barang virtualnya untuk membeli barang-barang elektronik berupa perlengkapan gaming. Pertanyaan selanjutnya adalah, mengapa jarak antara benda dan individu dapat berubah, sehingga nilai sebuah barang juga turut berubah? Hal tersebut akan dibahas pada bagian berikut.

\section{Dinamika Penilaian Barang Virtual}

Simmel menjelaskan bagaimana nilai sebuah barang berbanding relatif dengan posisi individu terhadap barang tersebut.Keenam informan mengalami perubahan posisi terhadap barang virtual selama mereka bermain game online. Dex misalnya, awalnya bermain game online bersama teman-temannya dan membeli barang virtual dengan menggunakan uang bulanan dari orangtuanya. Tujuan utama Dex adalah satu: mengalahkan teman-temannya dan menjadi yang terbaik. Pada saat ini, Dex berada di jarak yang tepat antara barang virtual dan dirinya, atau dengan kata lain, Dex berada di posisi sebagai pembeli.

Namun seiring dengan beerjalannya waktu, Dex tumbuh dewasa dan memutuskan untuk tinggal mandiri tanpa bantuan finansial orangtua.Pada saat inilah jarak antara Dex dan barang virtual mulai menjauh. Posisi Dex yang tinggal dengan kondisi finansial terbatas mendekatkan Dex dengan barang-barang lain seperti kulkas, televisi, serta barang-barang elektronik lain yang memiliki dampak langsung terhadap kenyamanan hidupnya. Dex tetap membeli barangbarang virtual, namun pada akhirnya Ia akan menjualnya kembali dan membeli barang nyata sebagai gantinya. Bagi Dex, barang nyata tersebut tetap memiliki nilai dan berfungsi sebagai pengingat terhadap pencapaiannya di dunia virtual.

Perubahan posisi juga terjadi pada informan lain, Skre. Skre yang awalnya merupakan kolektor kostum harus berhenti bermain karena desakan keluarga dan konstruksi gender di kepala orangtuanya.Skre berhenti bermain dan menjual seluruh kostumnya, serta mulai fokus berkerja dan mencari suami.Intervensi keluarga Skre membuat jarak antara Skre dan barang virtual menjadi renggang, menyebabkan perubahan nilai barang virtual dari sesuatu yang bernilai menjadi tidak bernilai.

"Jadi, enggak, enggak ini lah, ga didukung sama keluarga, ngapain sih kayak gitu-gitu dah cari kerja aja yang bener, Yee ini seminggu dapet dua juta tau!, tapi tetep aja kan keluarga tuh gasuka ngeliat ada seorang anak perempuan cantik seperti princess dirumah kerjanya main game... Akhirnya gua mutusin untuk berhenti main game dan gua kembali berkerja." (Hasil wawancara dengan Skre tanggal 19 Maret 2015)

Hal yang sama terjadi pada informan lain, Stitch. Ragnarok Online II mengalami penurunan jumlah pemain dalam kurun waktu dua tahun 
terakhir.Saat teman-temannya mulai berhenti bermain dan harga barang virtual mulai menurun, Stitch memutuskan untuk menjual karakter Ragnarok Online II nya. Alasan penjualan Stitch sangat rasional, "Ya mumpung masih jadi zeny, eh masih jadi duit". Ketiga paparan di atas menunjukkan bahwa konteks sosial mempengaruhi posisi seseorang terhadap barang virtual, dan mempengaruhi penilaian mereka terhadap barang tersebut.Sesuatu yang dianggap bernilai dapat menjadi tidak bernilai keesokan harinya.

Perubahan jarak juga berlaku secara kontekstual. Jadeith misalnya, mengalami perubahan dari pihak yang hanya mengamati dan tidak terlibat proses RMT dalam Ragnarok Online II menjadi penggila barang kosmetik di DotA II. Namun layaknya dua mata koin, selain informan yang mengalami perubahan jarak, terdapat pula informan yang selalu berada di jarak yang sama, dan memiliki penilaian yang sama terhadap barang virtual sepanjang sejarah bermain game mereka.

Caligula merupakan salah satu informan yang menganggap karakter sebagai barang yang sangat bernilai. Caligula sempat aktif menjual barangbarang kosmetiknya, namun, berbeda dari informan lain yang menjual karakternya ketika berhenti bermain, Caligula mengaku bahwa Ia tidak akan menjual karakternya. Bagi Caligula, karakter, khususnya nama karakter memiliki nilai emosional yang tidak dapat dikuantifikasikan menjadi uang. "Keterikatan emang gak sih kalo buat barang, gua keterikatan sama char nya, sama nicknamenya gitu-gitu", Ujar Caligula.

Caligula merupakan informan yang berasal dari kelas atas.Caligula tinggal di komplek apartemen mewah di daerah Bendungan Hilir. Berbeda dengan informan lain yang menggunakan uang hasil penjualan untuk membeli perlengkapan elektronik dan fashion, Caligula sudah memiliki budget tersendiri untuk membeli barang-barang tersebut. Hal inilah yang menyebabkan jarak antara Caligula dan barang virtual bersifat konstan, karena hasratnya terhadap barang lain dapat dipenuhi tanpa mengorbankan jarak antara dirinya dan barang virtual. Caligula sendiri masih memiliki karakter beserta beberapa kostum. Caligula sendiri menyebut karakternya sekarang sebagai "museum".

Selain Caligula, Cadreva juga mempunyai posisi yang tidak berubah terhadap barang virtual. Cadreva mulai mengenal game online saat duduk di bangku SMP. Cadreva merupakan informan yang secara kronologis terlibat paling awal dalam proses penjualan barang virtual. Saat masih berada di bangku SMA, Cadreva sudah berhasil menjual mata uang game Lineage II sebanyak tiga milyar, dan mendapatkan keuntungan sebesar Rp3.000.000,-. Hal ini Cadreva akui sebagai dampak dari hubungan sosialnya dengan pemain-pemain yang memiliki modal pengetahuan tentang cara mendapatkan uang di dalam dunia virtual.Cadreva sendiri memandang barang virtual sebagai sesuatu yang tidak bernilai, karena Ia mengetahui cara mendapatkan barang tersebut dengan mudah, atau mengenal orang yang memiliki akses terhadap barang tersebut.Hal inilah yang membuat posisi Cadreva berada di kategori penjual.

Cadreva, layaknya Dex, Stitch dan Skre juga menggunakan uang hasil penjualannya untuk membeli barangbarang di dunia nyata.Latar belakang di dunia ekonomi dan perpajakan membuat Cadreva menginvestasikan keuntungannnya di pasar saham, selain untuk biaya kuliah dan pembelian barang-barang elektronik.Hal ini menjadi menarik karena ada Informan 
yang penilaiannya terhadap barang virtual sangat dipengaruhi oleh faktor sosial, dan ada yang tidak. Skre dan Cadreva menganggap barang virtual tidak berharga karena faktor eksternal: keluarga dan teman bermain. Sebaliknya, keinginan Stitch untuk berjudi demi mendapatkan barang virtual serta keengganan Caligula untuk menjual barang-barang virtualnya merupakan bentuk kapasitas individu untuk memilih.

\section{Dualitas Posisi Aktor dalam Real Money Trade}

Paparan di atas menunjukkan poin yang menarik. Pembeli adalah pihak yang ingin melampaui jarak antara dirinya dengan barang tertentu, sedangkan penjual adalah pihak yang dengan sengaja memberi jarak antara dirinya dengan barang tertentu, demi memenuhi hasratnya terhadap barang lain. Paparan di atas menunjukkan analisa kegiatan menjual dan membeli secara terpisah.Namun, layaknya dua sisi mata koin, seluruh informan terlibat dalam aktivitas penjualan dan pembelian barang virtual secara bersamaan.

Dex, Stitch dan Skre misalnya, membeli berbagai barang virtual hanya untuk menjualnya kembali dan membeli barang nyata dari uang tersebut. Jadeith menggunakan uang hasil penjualan karakter untuk biaya warnet, sedangkan Cadreva sempat membayar jasa bot untuk mengumpulkan mata uang dalam game yang kemudian akan Ia jual. Caligula, informan yang paling terikat dengan karakternya juga melakukan praktek yang sama, membeli kostum dengan harga murah, menjualnya dengan harga yang lebih mahal, dan menggunakan uang tersebut untuk membeli kostum lain.

Dalam beberapa karyanya, Simmel membahas tentang dualitas.
Bagaimana dalam proses pertukaran seseorang mendapatkan sesuatu sekaligus mengorbankan sesuatu dan bagaimana konflik serta integrasi hadir secara bersamaan merupakan contoh pemikiran Simmel mengenai dualitas. Dalam kasus RMT konsep dualitas hadir dalam posisi penjual dan pembeli yang relatif tidak dapat dipisahkan karena seluruh informan terlibat dalam proses pembelian dan penjualan.

\section{E. Kesimpulan}

Simmel memandang proses pertukaran sebagai sesuatu yang unik. Pertukaran adalah permainan jarak. Individu mengorbankan jaraknya dengan sebuah benda, namun di saat yang sama melampaui jarak antara dirinya dengan benda yang lain. Dalam kerangka permainan jarak ini individu tidak dapat lagi dikotak-kotakkan menjadi pembeli atau penjual. Layaknya dua sisi koin, individu selalu menjadi penjual dan pembeli secara bersamaan dalam proses pertukaran. Saat jaraknya terhadap barang virtual mendekat, maka ia akan memaknai barang tersebut sebagai barang yang tidak bernilai dan menjualnya. Namun sebaliknya, saat jaraknya terhadap barang virtual menjauh, namun tidak terlalu jauh, ia akan menilai barang virtual tersebut bernilai dan berusaha melampaui jarak tersebut dengan menggunakan uang. Hal ini menunjukkan bahwa selain bersifat subjektif, pemaknaan individu terhadap barang virtual juga bersifat dinamis dan dapat berubah seiring berjalannya waktu.

Namun kita tidak dapat menganggap bahwa aktor yang terlibat dalam RMT berada di ruang hampa.Kapasitas aktor untuk memaknai barang secara subjektif selalu bersinggungan dengan faktor-faktor sosial seperti teman bermain, keluarga, 
serta pasar.Namun terlepas dari pengaruh faktor-faktor sosial, aktor tetap memiliki kapasitas untuk memaknai barang virtual secara subjektif. Faktor sosial hanya mempengaruhi keputusan aktor untuk membeli atau menjual barang virtual, sedangkan jenis, bentuk, atau variasi barang yang dibeli maupun dijual ditentukan sendiri oleh pemain yang bersangkutan.

\section{Daftar Pustaka}

Aarseth, Espen. (2004). Genre Trouble: Narrativism And The Art of Simulation. Cambridge: Mit Press.

Castronova, Edward. (2002). 'On Virtual Economies'.Cesifo Working Paper Number 752.Center Of Economic Studies

Corliss, Jonathan. (2010). 'Introduction: The Social Science Study Of Video Games'. Journal of Games And Culture 6(1):3-16.

Creswell, J. W. (2003). Research Design: Qualitative, Quantitative and Mixed Method Approaches. California: Sage Publication, Inc.

Heeks, Richard. (2008). 'Current Analysis and Future Research Agenda On "Gold Farming": RealWorld Production In Developing Countries For The Virtual Economies of Online Games. Development Informatics Paper Number 32.University of Manchester.

Koentjaraningrat. (1974). Pengantar Antropologi. Jakarta: Aksara Baru.

Lin, Holin dan Chuen-Tsai Sun. (2011).' Cash Trade In Free-To-Play Online
Games'. Journal of Games And Culture 6(3):270-287.

Neuman, W. Lawrence. (2006). Social Research Method: Qualitative and Quantitative Aproaches. Boston: Pearson Education, Inc.

Park, Bong-Won dan Kun-Chang Lee. (2011). 'Exploring The Value of Purchasing Online Game Items'. Journal of Computers In Human Behavior 27:2178-2185.

Ritzer, G., Goodman, D. J. (2011). Teori Sosiologi Modern. Jakarta: Kencana.

Simmel, Georg. (2005). The Philosophy of Money. London: Routledge. Sotiropoulou,

Irene. 2010. 'On Georg Simmel's Philosophy Of Money'. Rethymno Political Economy Workshop 2010.

\section{Sumber Internet}

'Real Money Trade'. (2014). Square Enix. Diakses pada Desember 15, 2014.

http://Support.Na.Square-

Enix.Com/Faqarticle.Php?Id=20\&

$\mathrm{Kid}=12802$ )

'The Early History of Real Money Trades'. (2006). Terranova Blog. Diakses Pada Desember 15, 2014. http://Terranova.Blogs.Com/Terr a_Nova/2006/01/The_Early_Histo ry.Html 